\title{
Network Endpoint
}

National Cancer Institute

\section{Source}

National Cancer Institute. Network Endpoint. NCI Thesaurus. Code C80357.

An individual user device on a data communication network. 